\title{
STUDI KELAYAKAN PENYEBERANGAN LAUT KENDARAANANGKUTANBARANG ANTARA PELABUHAN JANGKAR SITUBONDO-PELABUHAN LEMBAR LOMBOK NTB
}

\author{
Soni Sudarso ${ }^{1}$, Hary Moetriono ${ }^{1}$, Wateno Oetomo ${ }^{1}$, Sri Wiwoho Mudjanarko ${ }^{2}$ \\ ${ }^{1}$ Universitas 17 Agustus 1945 Surabaya \\ ${ }^{2}$ Universitas Narotama Surabaya
}

\begin{abstract}
ABSTRAKS
Studi Kelayakan Penyeberangan Laut untuk Kendaraan Angkutan Barang dari Jangkar Ke Lembar, bermaksud untuk menilai kelayakan dari aspek ekonomi, agar bisa menjadi daya tarik bagi pengusaha angkutan barang untuk mengalihkan atau tidaknya rute perjalanan. Sehingga Pengembangan Pelabuhan Penyeberangan Jangkar menjadi pelabuhan penyeberangan kapal ferry dengan tujuan langsung Lombok Nusa Tenggara Barat. Dan pergerakan menerus tujuan NTB-NTT yang melalui Pulau Bali, yang merupakan icon pariwisata Indonesia tidak lagi terbebani kendaraan angkutan barang. Sehingga relevan dengan adanya program nasional Tol Laut oleh pemerintah RI saatkini.

Dengan menghitung biaya operasi kendaraan angkutan barang akan diketahui besar biaya yang sebenarnya dikeluarkan oleh usaha angkutan barang antara Asembagus Situbondo - pelabuhan Lembar NTB melalui rute penyeberangan Ketapang - Gilimanuk, Pulau Bali dilanjut penyeberangan PadangBai - Pelabuhan Lembar senilai Rp. 5.380.338,--. Sedangkan tarif penyeberangan penyeberangan antara Surabaya - Lombok melalui pelabuhan Tanjung Perak menuju pelabuhan Lembar senilai Rp 4.574.000,- untuk golongan kendaraan angkutan barang yang sama.

Jadi jika diadakan penyeberangan angkutan barang dari Pelabuhan Jangkar di Asembagus Situbondo menuju Pelabuhan Lembar di Lombok NTB atau sebaliknya akan jauh lebih ekonomis sehingga layak untuk direalisasikan. Studi ini bisa menjadi informasi dasar dari pengambilan kebijakan publik untuk menunjang program pembangunan nasional.
\end{abstract}

Kata kunci : Studi Kelayakan, Rute Kendaraan Angkutan Barang Darat-Laut, Biaya Operasi Kendaraan. 


\section{DAFTAR ISI}

ABSTRAKSI

DAFTAR ISI

DAFTAR TABEL $\quad$ v

DAFTAR GAMBAR vi

\section{BAB I PENDAHULUAN}

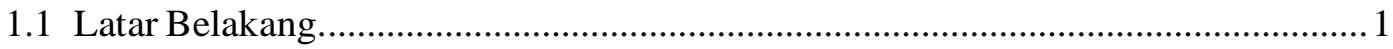

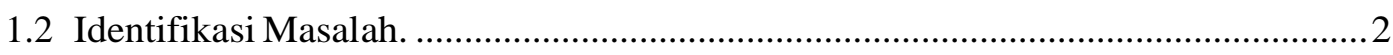

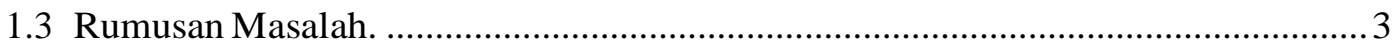

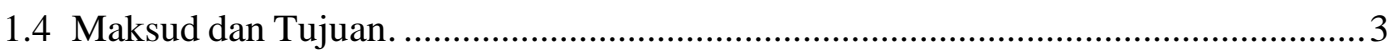

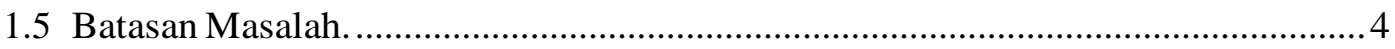

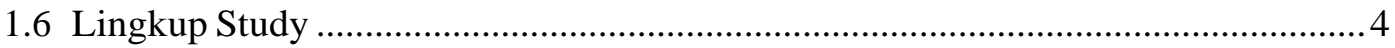

\section{BAB II KAJIAN PUSTAKA}

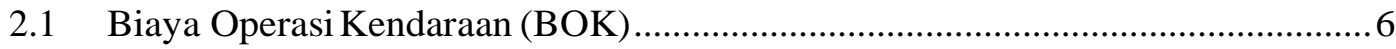

2.1.1 Perhitungan BOK dengan Rumus PCI Model. ............................................... 6

2.1.2 Perhitungan BOK Yang Dikembangan Oleh LAPI ITB ................................. 8

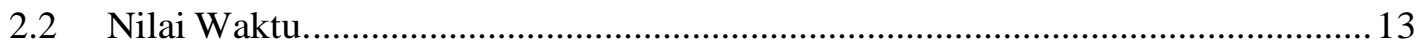

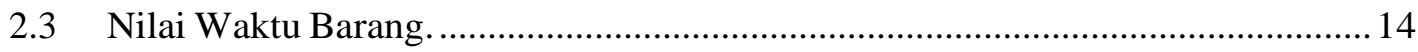

2.4 Kondisi Geometrik Jalan, Kecepatan Lalu Lintas Dan Kekasaran Permukaan Jalan

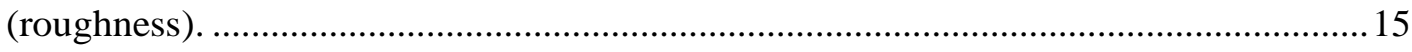

2.4 Tarif Penyeberangan Laut dan Biaya Operasi Kendaraan (BOK) ......................... 18

\section{BAB III METODOLOGI PENELITIAN}

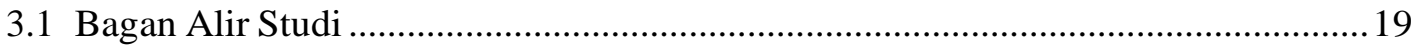

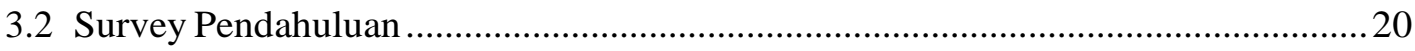

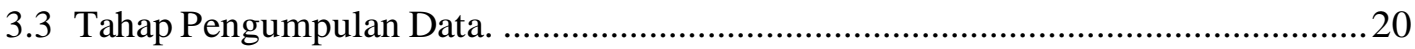

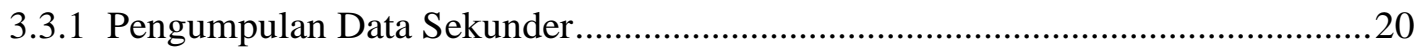




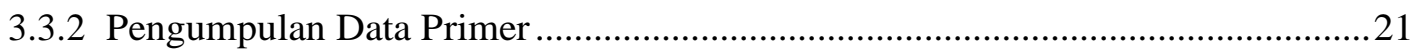

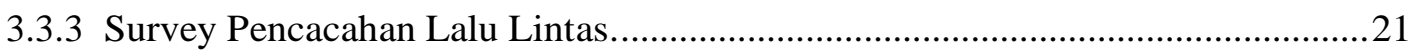

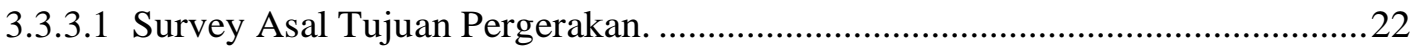

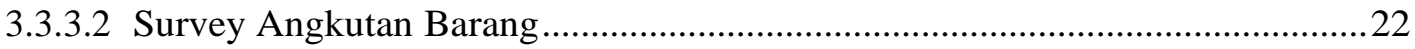

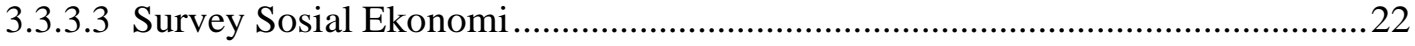

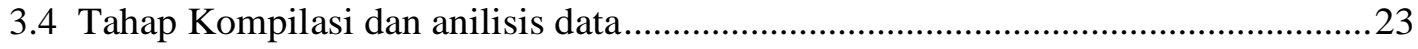

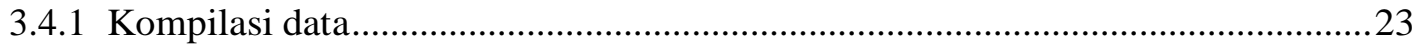

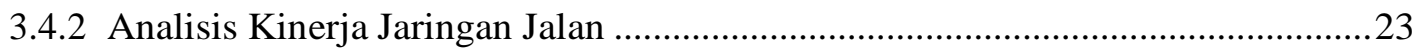

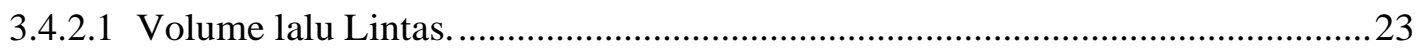

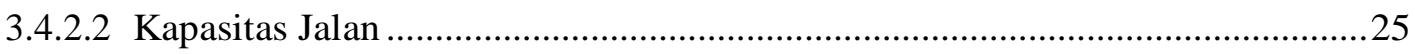

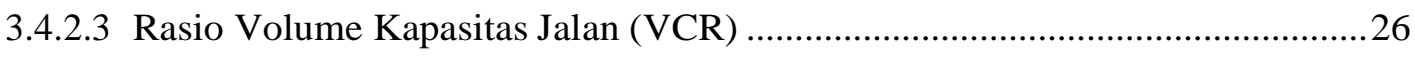

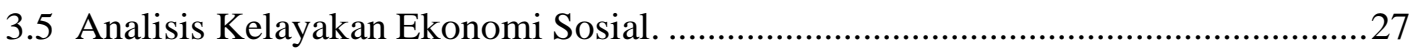

\section{BAB IV HASIL SURVEY DAN PEMBAHASAN}

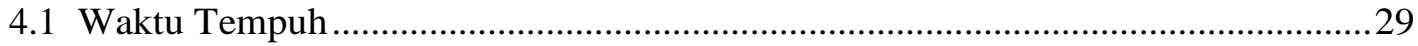

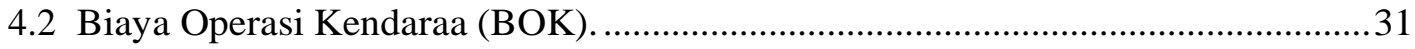

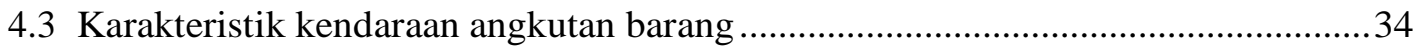

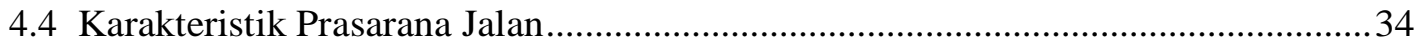

4.4 Perhitungan Biya Operasional Kendaraan. ......................................................... 35

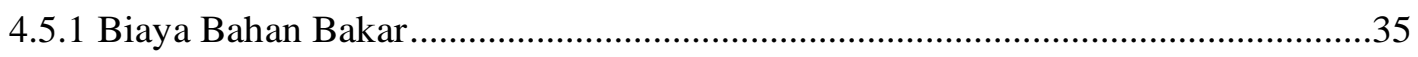

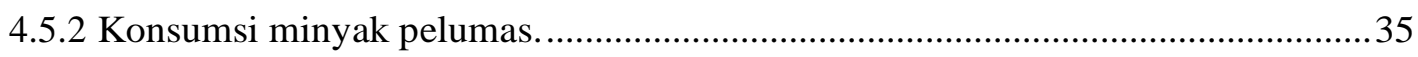

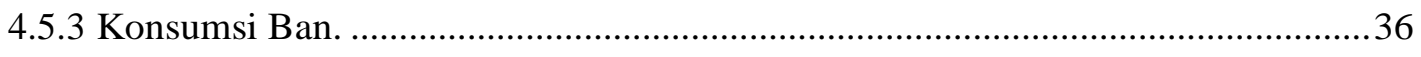

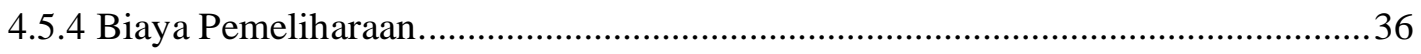

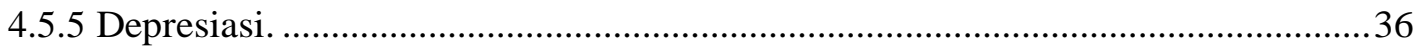

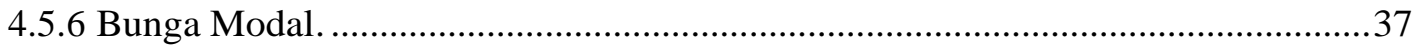

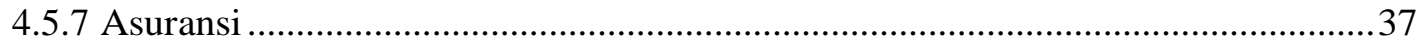

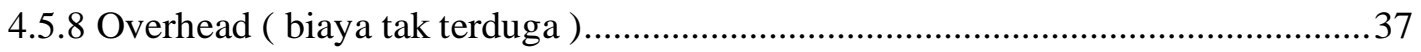

4.6 Biaya Tiket Penyeberangan antara Ketapang - Gilimanuk

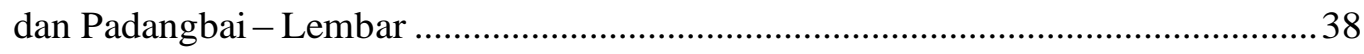




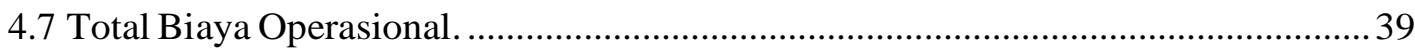

4.8 Perjalanan Kapal Dari Pelabuhan Tanjung Perak Ke Pelabuhan Lemba................... 39

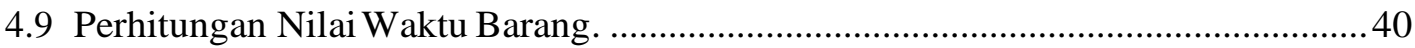

BAB V KESIMPULAN DAN SARAN

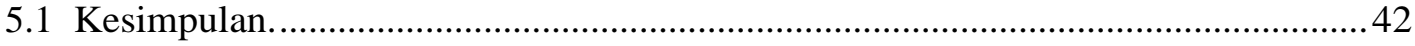

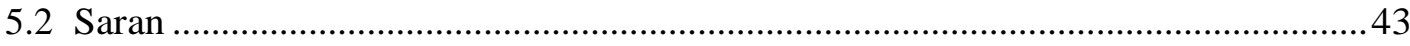

DAFTAR PUSTAKA 


\section{DAFTAR TABEL}

Tabel

Halaman

Tabel 2.1. Faktor Koreksi Akibat Kelandaian.............................................................

Tabel 2.2. Faktor Koreksi Akibat Kekasaran dan (v/c) ...........................................

Tabel 2.3. Konsumsi Dasar Minyak Pelumas (liter/km) ............................................. 10

Tabel 2.4 Faktor Koreksi Konsumsi Minyak Pelumas.................................................. 10

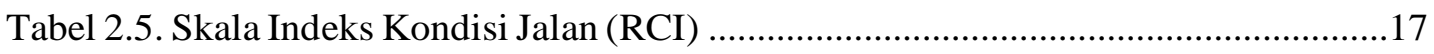

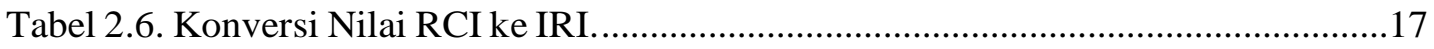

Tabel 3.1 Konversi dari kend/jam menjadi smp/jam berdasarkan jenis kendaraan (jalan

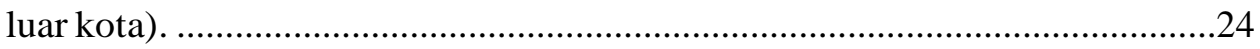

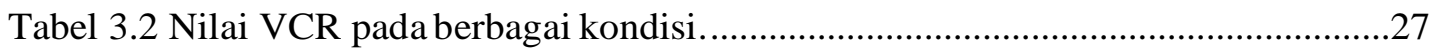

Tabel 4.1 Data hasil Survey Asal Tujuan Rute Gilimanuk - Padangbai. .......................... 30

Tabel 4.2 Data hasil Survey Asal Tujuan Rute Padangbai - Gilimanuk. ...........................30

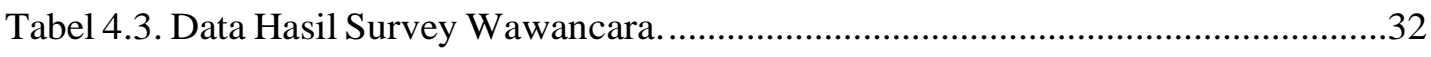

Tabel 4.4. Data Karakteristik Kendaraan Angkutan Barang .............................................

Tabel. 4.5. Rekapitulasi perhitungan Biaya Operasional Kendaraan.................................37

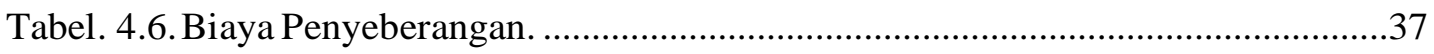

Tabel 4.7 Tarif Penyebrangan Tanjung Perak - Lembar .................................................39

Tabel 4.8 Nilai Waktu Angkutan Barang. ........................................................................ 


\section{DAFTAR GAMBAR}

Gambar

Halaman

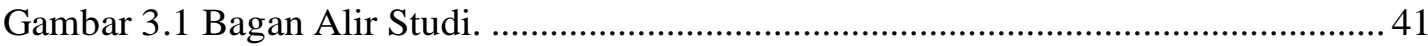

